\title{
Fluctuations and trends in the numbers of staging waterbirds in south Sweden in September 1973-2013
}

\author{
Fluktuationer och trender hos rastande sjöfåglar i södra Sverige i september \\ 1973-2013
}

LEIF NILSSON

\begin{abstract}
Regular September counts of staging waterbirds have been undertaken annually in south Sweden since 1973 as a complement to the International Midwinter Counts undertaken in January each year since 1967. The September counts aim to cover the population development of staging waterbirds, especially relating to species that are not wintering in the country. Between 150 and about 200 sites have been included in the calculation of the September indices, using the TRIM method. September indices were calculated for 18 species. The trends over the entire 41-year period were significantly increasing for all but five species (Anas platyrhynchos, Somateria mollissima

and Mergus serrator decreasing, whereas Podiceps cristatus and Fulica atra did not show any clear long-term trend). The September indices were in good agreement with the International Midwinter Counts and the winter counts of the Swedish Bird Survey, but much less well with migration counts at Falsterbo and breeding season counts of the Swedish Bird Survey. For the last ten years of the series, six species showed a significantly increasing trend, whereas four species decreased.

Leif Nilsson, Department of Biology, Ecology Building, SE-22362 Lund, Sweden. leif.nilsson@biol.lu.se
\end{abstract}

Received 26 March 2014, Accepted 27 October 2014, Editor: S. Svensson

\section{Introduction}

In the mid-sixties it was realised that a coordinated international effort was needed to monitor population size and trends of waterfowl, and the location and importance of their staging and wintering areas. This led to the organization of the International Waterbird Census (IWC) with the first International Midwinter Count in January 1967 (Atkinson-Willes 1969). January was chosen for the census as the waterfowl are generally most concentrated during the winter, most of them in addition staying in the more densely populated regions of Europe, where the chances to recruit enough counters were relatively good. Sweden has taken part since the start of the counts (Nilsson 1975, Nilsson 2008).

Even if the January counts are the most suitable for monitoring the total population sizes on a continental scale they do not reflect the use of different sites in different countries during other times of the year, when important local concentrations may occur. Some countries like the UK (Austin et al. 2014, Owen et al. 1986) and the Netherlands (Hornman 2013) undertake monthly counts annually to cover this aspect. In Sweden, monthly counts were run at about 120-200 sites annually during 1959/1960 1974/1975 (Nilsson 1968, 1976).

International counts in November, March and September were introduced in 1969-1976 as a complement to the midwinter counts (Nilsson 1977, 1980a, 1980b). In Sweden, only the September counts, started in 1973, were kept to cover the changes and trends in the autumn staging populations (Nilsson 1980a). The geese were covered in a special project, see Nilsson (2013a).

In the present contribution I will analyse the first forty-one years of September counts of waterbirds in south Sweden. The main emphasis will be on the changes in numbers and especially to establish whether there are any significant trends in these populations. September indices for important waterfowl species have regularly been published in the annual reports and on the homepage of the project: http://www.zoo.ekol.lu.se/waterfowl/index.htm).

\section{Material and Methods}

The International Waterbird Counts in Sweden as in the other countries rely on voluntary counters, which cover one or more counting units at the 
specified dates. Volunteers were originally recruited by contacting large numbers of bird watchers and other people that could be interested, but also via local bird clubs, bird magazines etc. In this way a network of observers was built up, some sites being covered by one or a few observers, whereas bird clubs or other groups of counters together covered other areas. The national September counts are organized in the same way as the International Midwinter Counts (cf. Nilsson 2008 and references therein).

The September counts cover a subset of the sites and reference areas used in the midwinter count. During the first years of the midwinter counts, the observers freely selected the sites to be covered but from 1986/1987 the counts for index calculations were standardized and a representative selection of larger coastal and inland areas (reference areas) was covered each year to give the basis for index calculations. These areas were built up of a number of smaller counting units, which were counted separately. In addition to the reference areas, counts from smaller sites spread over the country were also collected for the index calculations. About 20-25 percent of the midwinter sites are included in the September counts.

The September counts are organized on the weekend with the Sunday closest to 15 September. The week after is used as reserve period in case of bad weather conditions during the main counting date.

During the shore-based counts the observer covered the counting sector(s) either by walking the shore line or from vantage points using telescope, moving between vantage points as fast as possible to minimize the effects of movements of the birds. The counting sectors were normally covered within the same day.

Population trends were calculated using TRIM (TRends and Indices for Monitoring data; Pannekoek \& van Strien 2001), a statistical package developed especially for monitoring data of the kind we have. TRIM analyses time series of counts with missing observations using Poisson regression taking serial correlation and over-dispersion into account. We used the "time-effect model" to estimate overall trends as well as yearly indices. For more information, see Pannekoek \& van Strien (2001). The index value was set to 1 for the year 2000 . Trends were calculated both for the whole forty-one year period (called long-term trend) and for the most recent ten years (called short-term trend).

The number of sites covered in different years during the September counts is shown in Table 1.
Table 1. Number of sites covered at the September counts in different years, 1973-2013.

Antal lokaler inventerade vid Septemberinventeringarna under olika år, 1973-2013.

\begin{tabular}{|l|r|r|r|}
\hline $\begin{array}{l}\text { Year } \\
\text { Ar }\end{array}$ & \multicolumn{3}{|c|}{$\begin{array}{l}\text { Total number of sites counted } \\
\text { Antal inventerade lokaler }\end{array}$} \\
\hline & Coast & Inland & Total \\
\hline 1973 & 120 & 162 & 282 \\
\hline 1974 & 327 & 717 & 1044 \\
\hline 1975 & 333 & 231 & 564 \\
\hline 1976 & 289 & 188 & 477 \\
\hline 1977 & 283 & 185 & 468 \\
\hline 1978 & 292 & 123 & 415 \\
\hline 1979 & 177 & 111 & 288 \\
\hline 1980 & 168 & 93 & 261 \\
\hline 1981 & 168 & 65 & 233 \\
\hline 1982 & 167 & 65 & 232 \\
\hline 1983 & 130 & 80 & 210 \\
\hline 1984 & 171 & 68 & 239 \\
\hline 1985 & 164 & 64 & 228 \\
\hline 1986 & 156 & 55 & 211 \\
\hline 1987 & 136 & 58 & 194 \\
\hline 1988 & 133 & 75 & 208 \\
\hline 1989 & 142 & 61 & 203 \\
\hline 1990 & 108 & 60 & 168 \\
\hline 1991 & 118 & 57 & 175 \\
\hline 1992 & 137 & 66 & 203 \\
\hline 1993 & 147 & 72 & 219 \\
\hline 1994 & 117 & 71 & 188 \\
\hline 1995 & 124 & 62 & 186 \\
\hline 1996 & 115 & 66 & 181 \\
\hline 1997 & 108 & 65 & 173 \\
\hline 1998 & 117 & 75 & 192 \\
\hline 1999 & 110 & 63 & 173 \\
\hline 2000 & 138 & 53 & 191 \\
\hline 2001 & 116 & 72 & 188 \\
\hline 2002 & 128 & 62 & 190 \\
\hline 2003 & 130 & 57 & 187 \\
\hline 2004 & 121 & 55 & 176 \\
\hline 2005 & 125 & 61 & 186 \\
\hline 2006 & 109 & 55 & 164 \\
\hline 2007 & 116 & 45 & 161 \\
\hline 2008 & 130 & 54 & 184 \\
\hline 2009 & 135 & 48 & 183 \\
\hline 2010 & 124 & 52 & 176 \\
\hline 2011 & 137 & 34 & 171 \\
\hline 2012 & 139 & 42 & 181 \\
\hline 2013 & 108 & 16 & 124 \\
\hline & & & \\
\hline & & & 53 \\
\hline
\end{tabular}

During the first years a high number of sites were covered, especially in 1974, when aerial surveys were undertaken in some areas (cf. Nilsson 1980a), but during the last 30 years 161-239 sites have been covered annually. The sites have been distributed over the southern part of the country as shown 


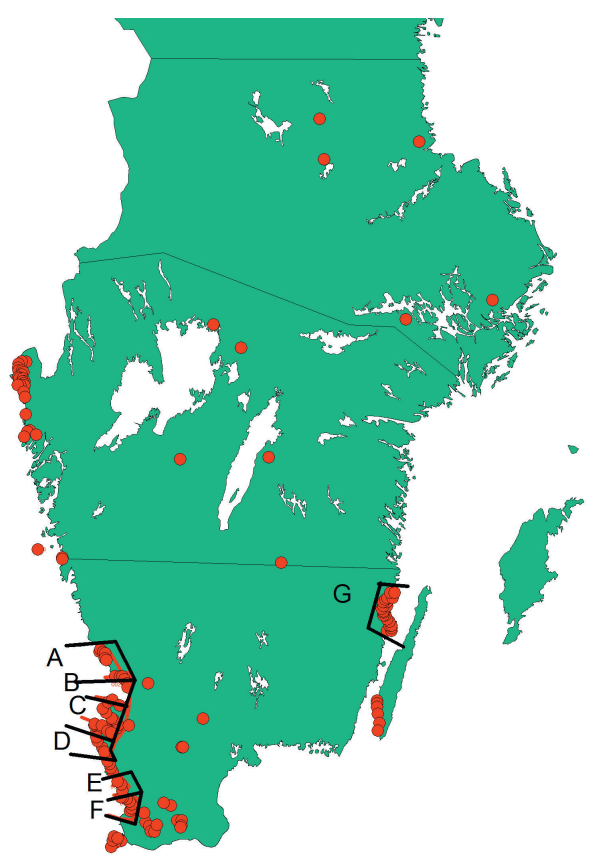

Figure 1. Map of south Sweden showing the sites included in the calculation of September indices. Areas marked with black (A-G) represent reference areas which have been counted in the same way during the years.

A = Tylön - Falkenberg, B = Laholmsbukten, $\mathrm{C}=$ Skälderviken, $\mathrm{D}=\mathrm{N}$ Öresund, $\mathrm{E}=$ Lundåkrabukten, $\mathrm{F}=$ Lommabukten and $\mathrm{G}=\mathrm{N}$ Kalmarsund.

Karta över södra Sverige utvisande de lokaler som ingår $i$ beräkningarna av Septemberindex. De med svart markerade områdena $A-G$ representerar referensområden, vilka räknats på samma sätt genom åren.

in Figure 1. Seven reference areas from the midwinter counts (six on the west coast and Öresund and one on the east coast) have been covered in the same way in September as at the midwinter counts.

The number of sites included in the index calculations has varied between 136 and 192 for the last thirty years (Table 1), being somewhat higher during the first years of the survey. After 1982 the proportion of index sites that were common with the previous year has been lower than $80 \%$ in only a few years.

\section{Results}

Below the trends and changes in numbers will be presented and discussed separately for each species. Indices are calculated for the whole of south Sweden for eighteen of twenty species analyzed in this paper. For two species, the marine offshore scoters Melanitta, the actual counts in the six reference areas on the west coast are given instead of an index. For some common species, totals for some or all of the seven reference areas are presented separately to elucidate regional variation. Separate total counts are also given for three species that have particularly impressive September populations in the two big bird-lakes Hornborgasjön and Tåkern.

For information on total numbers counted of the different species in different years see the annual reports that can be downloaded from the homepage http://www.zoo.ekol.lu.se/waterfowl/index.htm

Great Crested Grebe Podiceps cristatus (Figure 2) In September, the Great crested Grebe is mostly found on the inland lakes, but smaller numbers are also found at the coasts. The species has normally been quite well spread. There was no significant long-term trend. During the first fifteen years there was a decrease to an all-time low in 1987 followed by fluctuations around a more or less stable level, and after 2000 an increase to peak levels in 2004-2006. For the last ten years the trend was significantly decreasing, in 2013 reaching almost the same low level as in 1987.

Cormorant Phalacrocorax carbo (Figure 3)

The September indices for the Cormorant are most representative for the west coast of Sweden including the Öresund as the majority of Baltic Cormo-

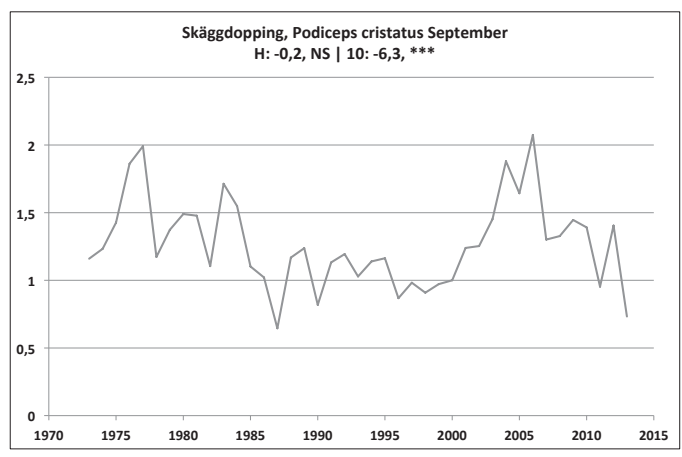

Figure 2. September indices for the Great crested Grebe Podiceps cristatus 1973-2013. The figures under the species name gives trend data, $\mathrm{H}=$ whole series, $10=$ last decade, annual change in per cent over the period is given followed by information on significance levels for the trends, NS = not significant.

September index för skäggdopping 1973-2013. Siffrorna under namnet ger trenddata H för hela perioden, 10 = för den senaste tioårsperioden; därefter följer procentförändringen under resp. period samt signifikansnivån för trenden, $N S=$ inte signifikant. 

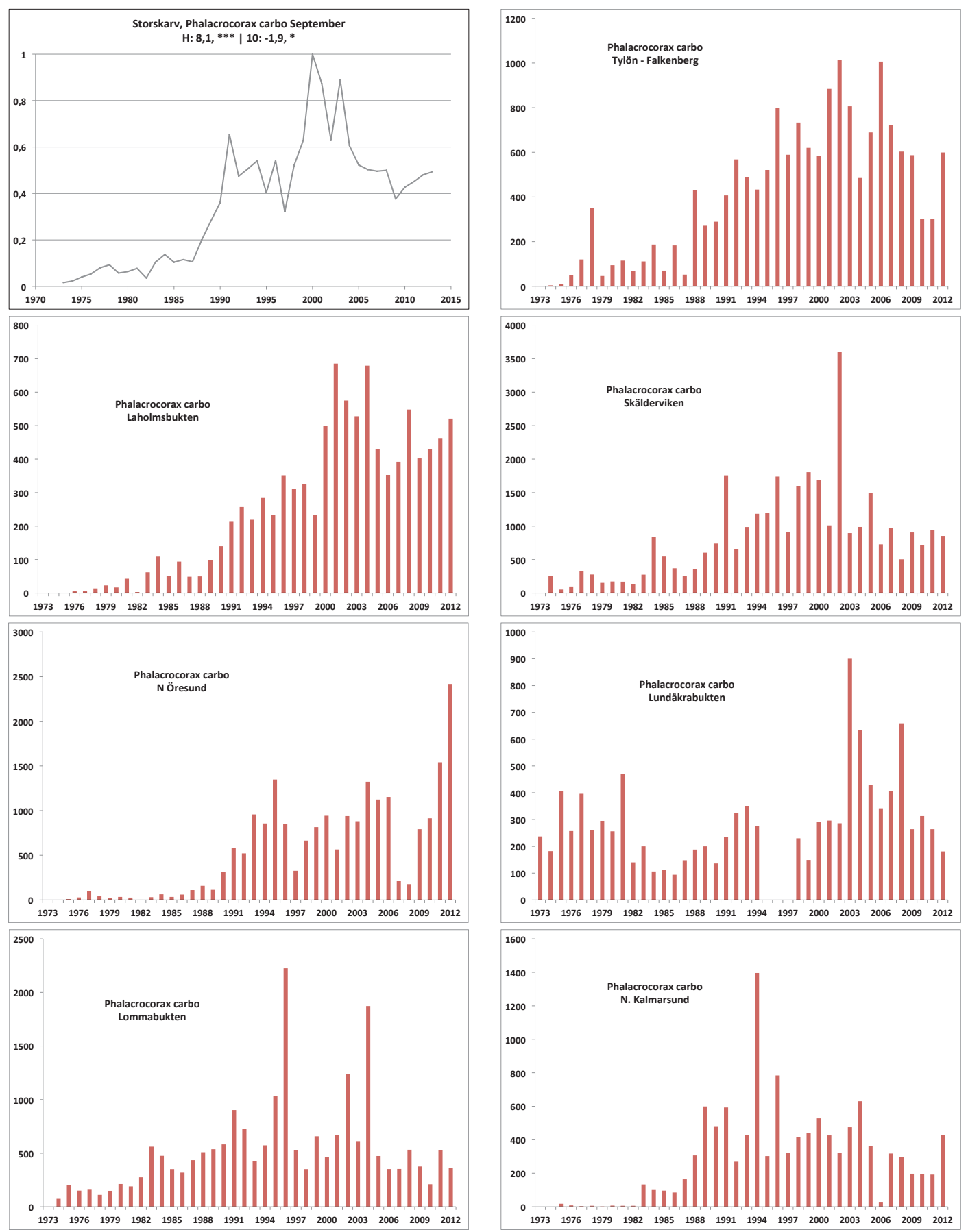

Figure 3. September indices for the Cormorant Phalacrocorax carbo 1973-2013 and the numbers counted in some reference areas (Figure 1) 1973 - 2012. The figures under the species name in the index diagram gives trend data, $\mathrm{H}=$ whole series, 10 $=$ last decade, annual change in per cent over the period is given followed by information on significance levels for the trends, $\mathrm{NS}=$ not significant.

September index för storskarv 1973-2013 samt antalet inräknade i några referensområden (Figur 1) 1973-2012. Siffrorna under namnet ger trenddata $H$ för hela perioden, 10 = för den senaste tioårsperioden; därefter följer procentförändringen under resp. period samt signifikansnivån för trenden, $N S=$ inte signifikant. 


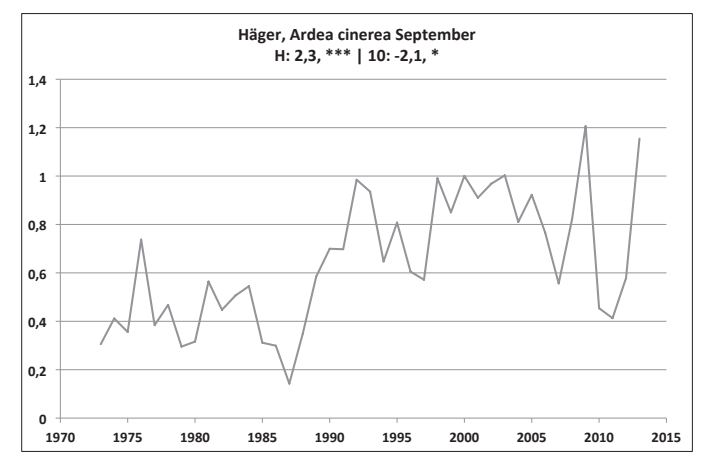

Figure 4. September indices for the Heron Ardea cinerea 1973-2013. For more information see Figure 2.

September index för häger 1973-2013. Se vidare Figur2.
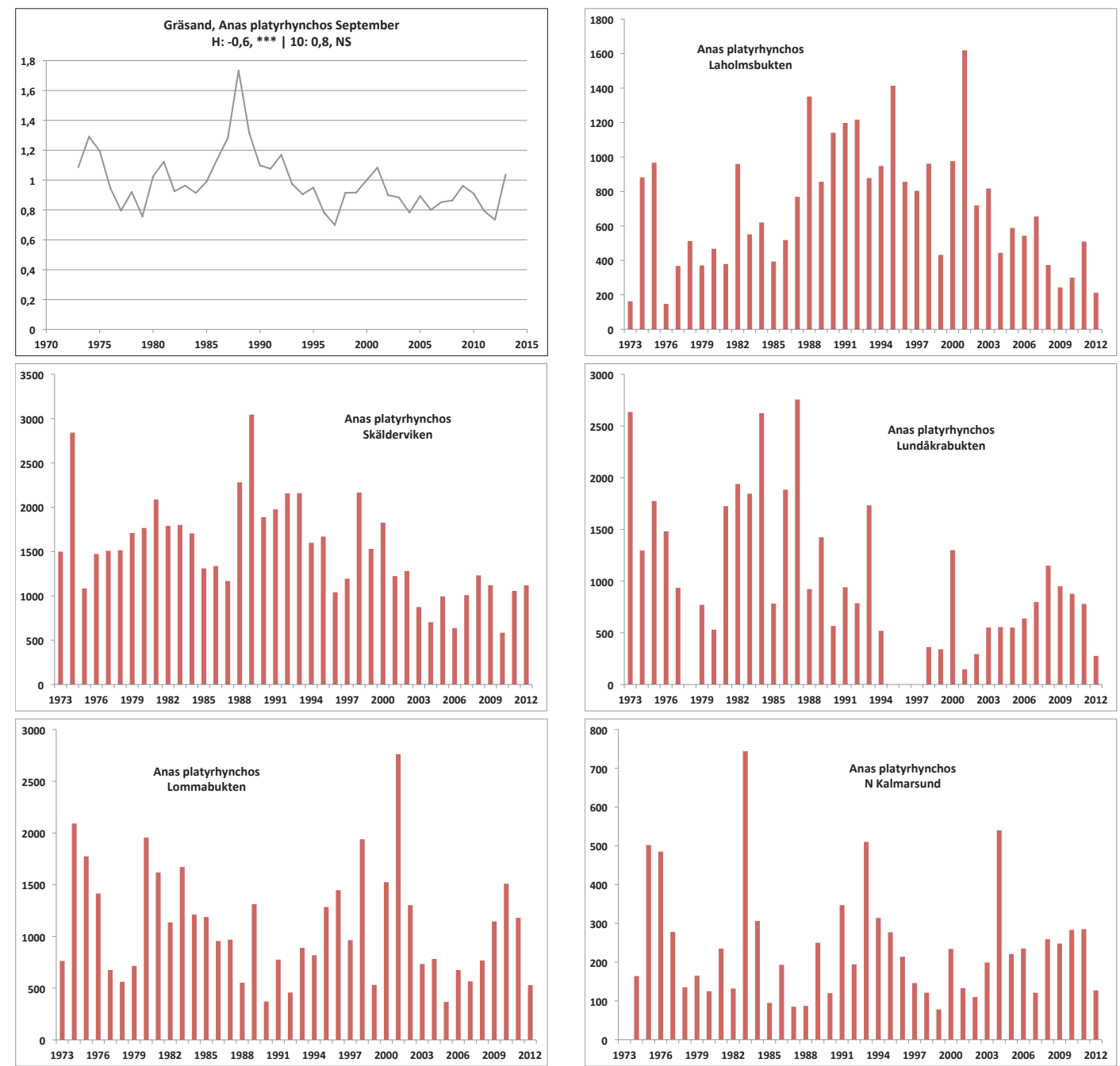

Figure 5. September indices for the Mallard Anas platyrhynchos 1973-2013 and the numbers counted in some reference areas. For more information see Figure 3.

September index för gräsand 1973-2013 samt antalet inräknade i några referensområden. Se vidare Figur 3. 
rants occur in the archipelagoes which were not adequately covered. The long-term trend showed a significant increase, but the trend for the last decade was decreasing after a peak around year 2000 . The Cormorant was common in the reference areas on the west coast. In all areas except Lundåkrabukten, the numbers were low at the start of the counting period and increased over the years. Lommabukten showed a similar picture but the increase levelled off earlier. Lundåkrabukten did not show any trend but only marked fluctuations. In the only reference area studied on the east coast, very few Cormorants were found during the first fifteen years. Numbers during the last twenty years of the series varied between 200 and 600 with one larger count.

Grey Heron Ardea cinerea (Figure 4)

The indices for the Heron show a significantly increasing long-term trend, whereas the trend for the last decade was decreasing and significant. The Heron indices started to increase during the mild winters after the cold winter in 1987 (before that we had a period of shifting hard and mild winters). After 1990 the numbers have fluctuated about a rather steady level but with particularly low indices in 2010 and 2011, which followed after two other hard winters. 2009 had the highest index for the species, after a mild winter, but the index for 2013 was nearly as high.

\section{Mallard Anas platyrhynchos (Figure 5)}

The long-term September trend was significantly decreasing. There was no clear trend during the last decade. The number of Mallards counted in four reference areas on the west coast and the one on the east coast showed much variation between the years. There was a clear decrease during later years in three of them but not in the other two. September 1985 had a very high index due to unusually large numbers counted on three different inland lakes in south Sweden.

\section{Teal Anas crecca (Figure 6)}

In contrast to the Mallard, the Teal showed a significantly increasing trend both over the entire counting period and during the last decade. However, the significance of the long-term trend depends exclusively on the increase during the last decade. Large numbers of Teal were counted in three of the reference areas, two in Öresund and one in Skälderviken. Numbers in all three areas showed much variation between years, and there was no significant
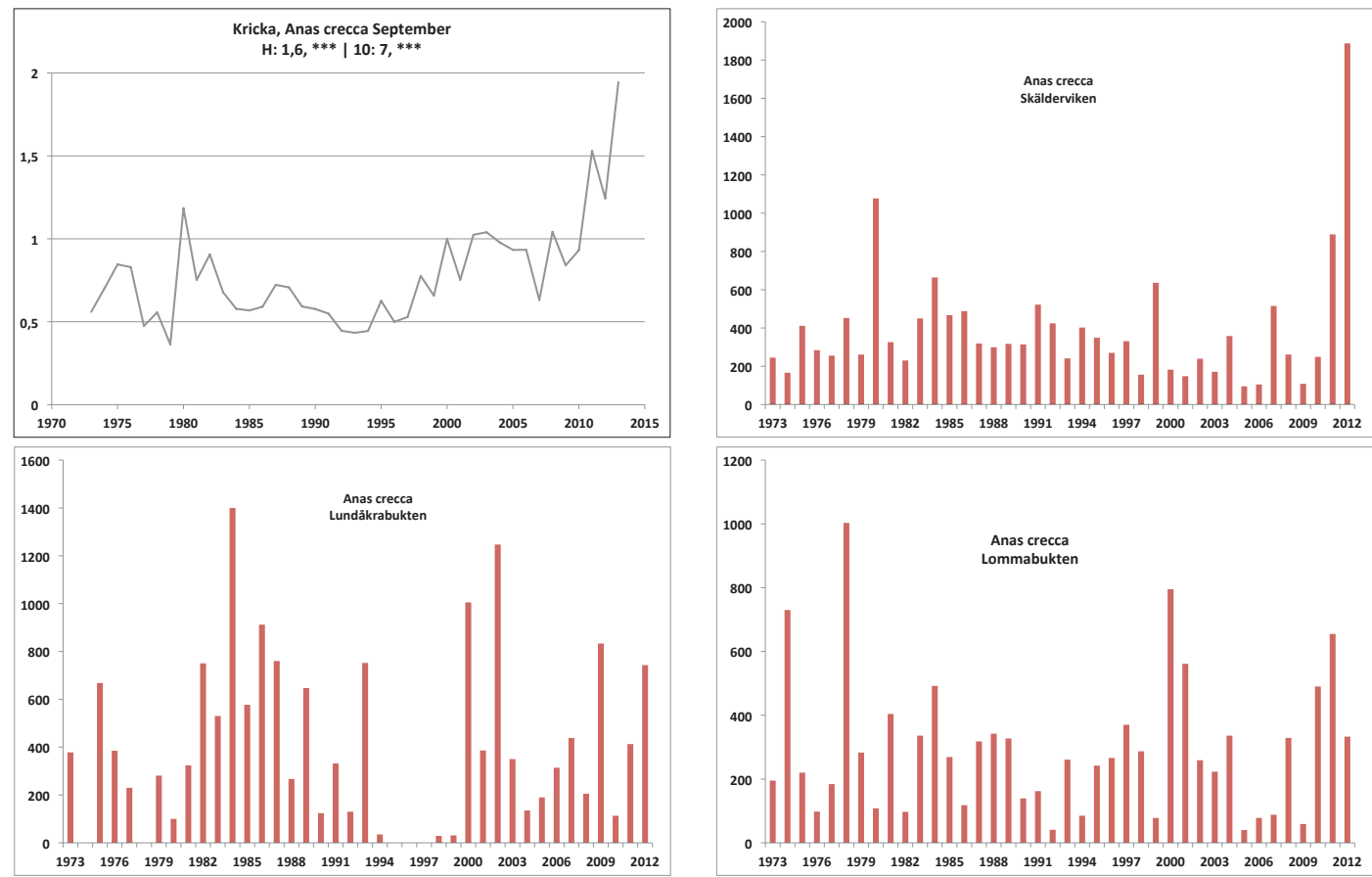

Figure 6. September indices for the Teal Anas crecca 1973-2013 and the numbers counted in some reference areas. For more information see Figure 3.

September index för kricka 1973-2013 samt antalet inräknade i några referensområden. Se vidare Figur 3. 

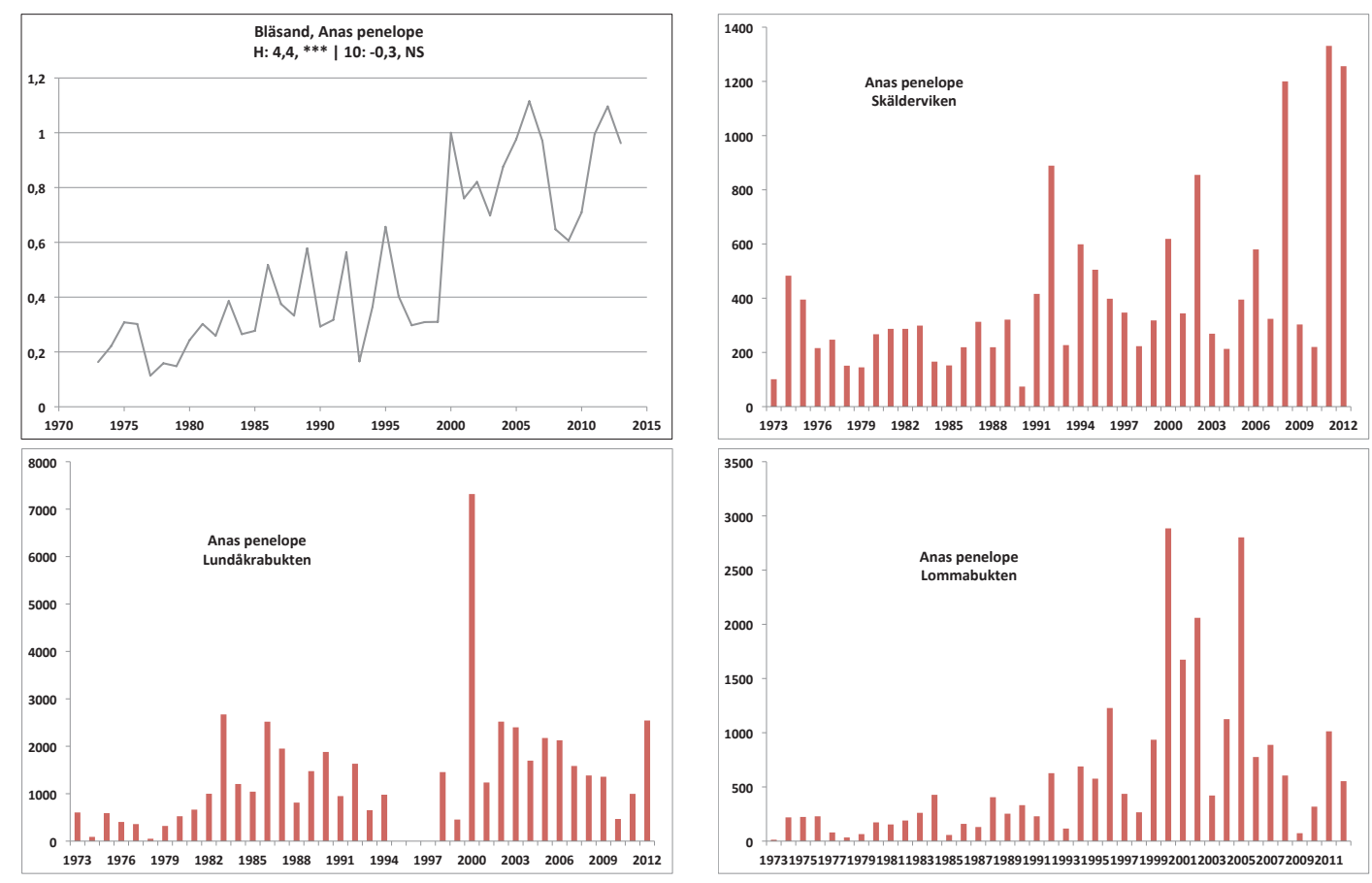

Figure 7. September indices for the Wiegon Anas penelope 1973-2013 and the numbers counted in some reference areas. For more information see Figure 3.

September index för bläsand 1973-2013 samt antalet inräknade i några referensområden. Se vidare Figur 3

trend in any of them. There were several aberrantly high peak counts in all three areas.

\section{Wigeon Anas Penelope (Figure 7)}

In contrast to the Mallard but similar to the Teal, there was a significantly increasing long-term trend in the numbers of staging Wigeons. For the last decade there were marked fluctuations between years but no significant trend. Larg numbers of Wigeon were counted in three of the reference areas, in Skälder-

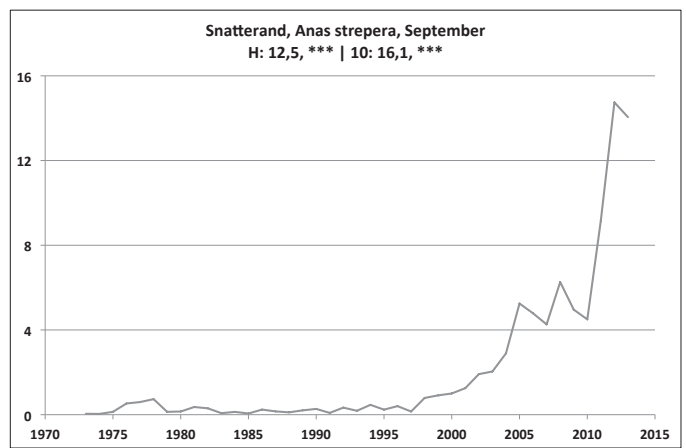

viken and in Lommabukten and Lundåkrabukten in Öresund. In all three areas, there was a marked fluctuation between years but in general counts were higher in the latter part of the series both for Skälderviken and Lommabukten, whereas no such tendency was found for Lundåkrabukten.

Gadwall Anas strepera (Figure 8)

During the first twenty five years, the Gadwall was a rare species in the protocols from the Septem-

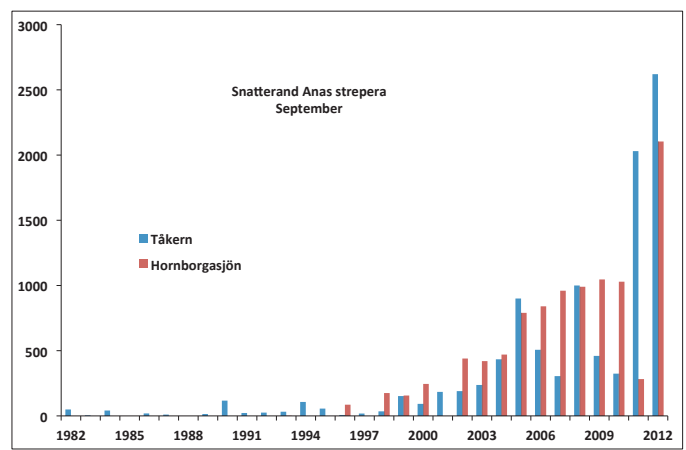

Figure 8. September indices for the Gadwall Anas strepera 1973-2013 and the numbers counted in two important bird lakes. For more information see Figure 3.

September index för snatterand 1973-2013 samt antalet inräknade i två viktiga fågelsjöar. Se vidare Figur 3. 


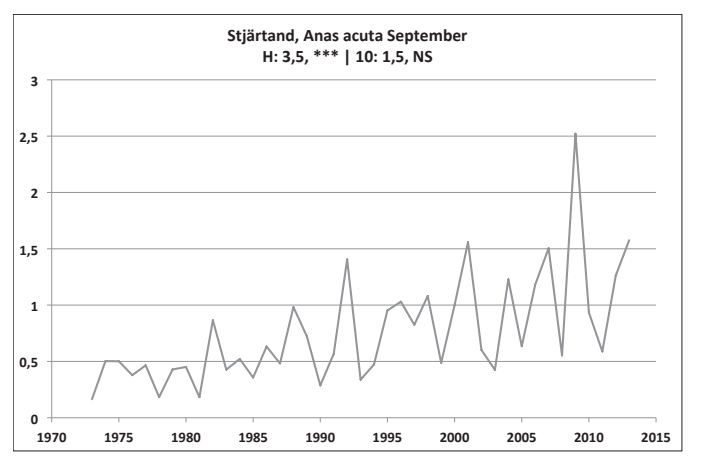

Figure 9. September indices for the Pintail Anas acuta 19732013. For more information see Figure 2.

September index för stjärtand 1973-2013. Se vidare Figur 2.

ber counts, but during the last fifteen years a very marked increase was recorded, and both the longterm trend and the trend for the last decade were increasing and highly significant. This was especially marked at the two bird-lakes Hornborgasjön and Tåkern, where hardly any were seen during the first decades and no less than 2100 and 2600 were counted in September in 2012, respectively. The species was also more common on other sites in the counts but numbers here were much lower.

\section{Pintail Anas acuta (Figure 9)}

Pintails were regularly found mostly in small numbers on a number of counting sites. In general less than 100 Pintails were counted on the west coast reference areas taken together, but there was much variation between years. The maximum total for these areas was 450. The long-term trend for south Sweden was increasing and significant. No significant trend was found for the last ten years.

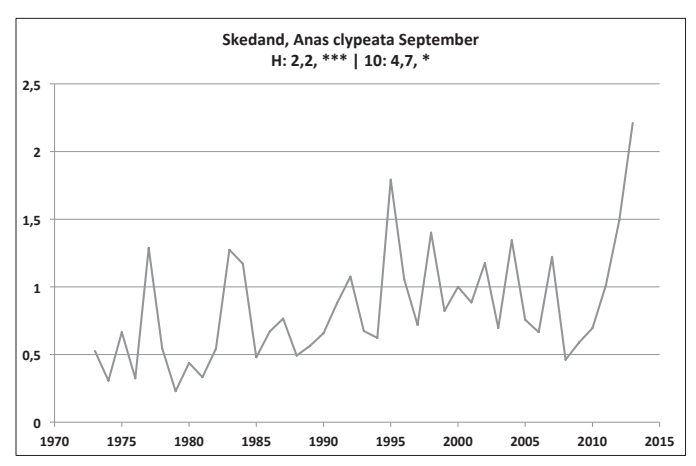

Figure 10. September indices for the Shoveler Anas clypeata 1973-2013. For more information see Figure.2.

September index för skedand 1973-2013. Se vidare Figur 2.

Shoveler Anas clypeata (Figure 10)

The Shoveler was regularly found on the west coast reference areas, mostly with annual totals less than 50 individuals for the five areas together. Totals of more than 200 were noted in two years during the entire series of counts. The indices showed a significantly increasing trend both for the entire series and for the last decade. However, the significance of the ten year trend is exclusively due to the value of 2013.

Tufted Duck Aythya fuligula (Figure 11)

Tufted duck were well distributed over the inland sites and east coast areas. Marked fluctuations were found between different years, but the long-term trend was significant and increasing. Numbers were small in the reference areas on the west coast, but between 500 and $>4000$ were counted in different years in the reference area in northern Kalmarsund.
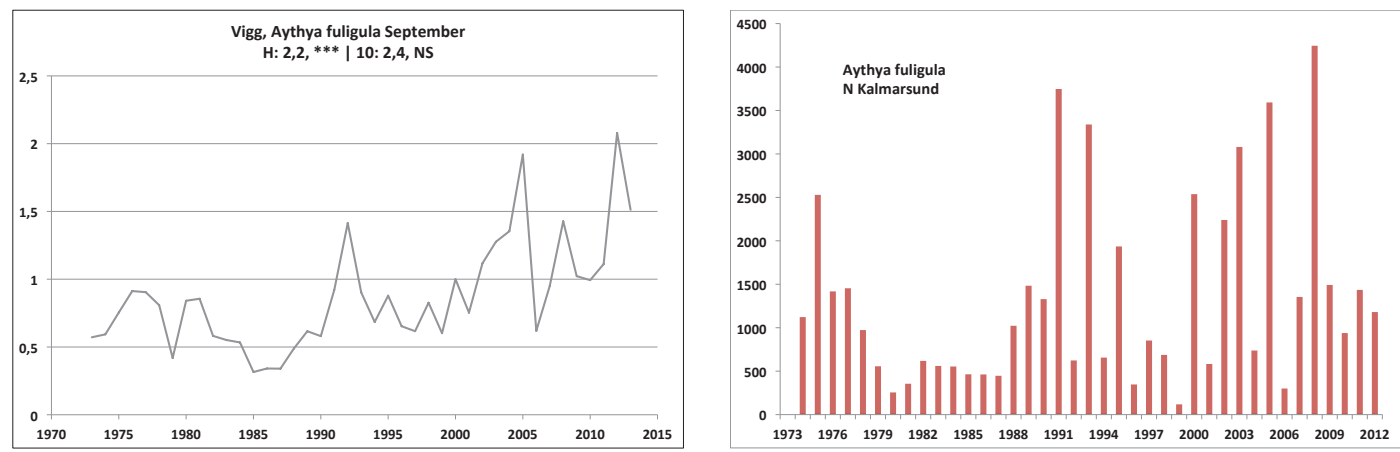

Figure 11. September indices for the Tufted Duck Aythya fuligula 1973-2013 and the numbers counted in a reference area in Kalmarsund. For more information see Figure 3.

September index för vigg 1973-2013 samt antalet inräknade i ett referensområde i Kalmarsund. Se vidare Figur 3. 

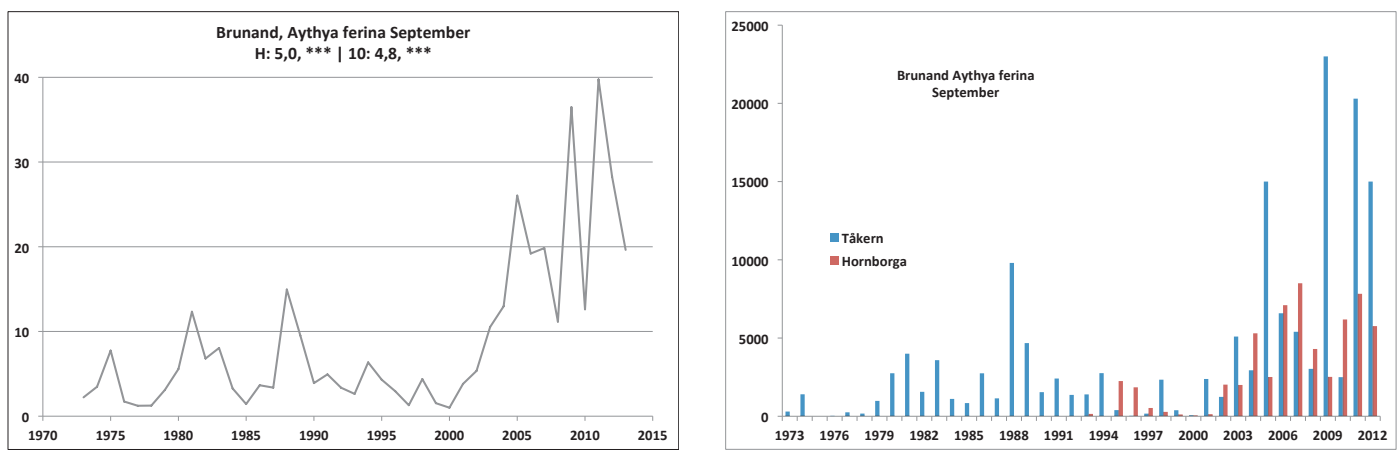

Figure 12. September indices for the Pochard Aythya ferina 1973-2013 and the numbers counted in two important bird lakes. For more information see Figure 3.

September index för brunand 1973-2013 samt antalet inräknade i två viktiga fågelsjöar. Se vidare Figur 3.

\section{Pochard Aythya ferina (Figure 12)}

The trends were increasing and significant both for the long-term period and, particularly, the last decade. The Pochards were mostly concentrated to a few (often one or two) sites with huge flocks in later years in addition to smaller numbers found in a number of other lakes and coastal sites. During the years before 2000, the large flocks were found in Lake Tåkern, maximum totals normally being less than 5000. During the last decade large flocks also appeared at Lake Hornborgasjön in some years. In two years more than 20000 were counted in Lake Tåkern, whereas peak totals at Lake Hornborgasjön were between 7000 and 8000 in two years. Rather than as a linear increase the changes of this species can more correctly be described as fluctuations around a more or less steady level until a marked increase started around year 2000 .

\section{Goldeneye Bucephala clangula (Figure 13)}

The Goldeneye is a well spread species on both inland and coastal waters in September. The overall indices show a significant increase over the entire series. The trend for the last ten years was also significantly increasing but it is markedly influenced by one year with a very high index value. The counts in the reference areas do not show any clear trend over the period but only marked fluctuations between years. Skälderviken showed a slight tendency to a decrease but the fluctuations between years were quite marked also for this area.

\section{Velvet Scoter Melanitta fusca \& Common Scoter Melanitta nigra (Figure 14)}

The two scoters are mostly to be found in offshore waters and are normally seen only in small numbers in the counts undertaken from the shoreline.
One exception is the southern part of the Kattegat, where large flocks of both species are found within distances that normally can be covered from the shore in Laholmsbukten and to a smaller extent in Skälderviken. During the early years of the September counts large flocks were found in Laholmsbukten. In the following years numbers were much smaller, but during the last few years more scoters were once again found in the area. The Velvet Scoter was the most common species during the first years, whereas the Common Scoter was the most common species in the later years.

Eider Somateria mollissima (Figure 15)

The Eider indices showed a significantly decreasing long-term trend. If different time periods are considered there was an increase during the first ten to twelve years followed by a marked decrease. The indices for the last ten years do not show any significant change. The Eider totals for the seven reference areas show much variation between years but in general there is a decreasing tendency in all of them with the exception of Lundåkrabukten.

\section{Red-breasted Merganser Mergus serrator (Figure 16)}

During the first years until 2004, the indices for the Red-breasted Merganser indicated marked fluctuations around a decreasing trend, and the trend for the entire period is also significantly negative. No significant trend was found for the last ten years.

Goosander Mergus merganser (Figure 17)

The overall indices show a weak but significantly increasing long-term trend. There was no significant trend for the last decade. 

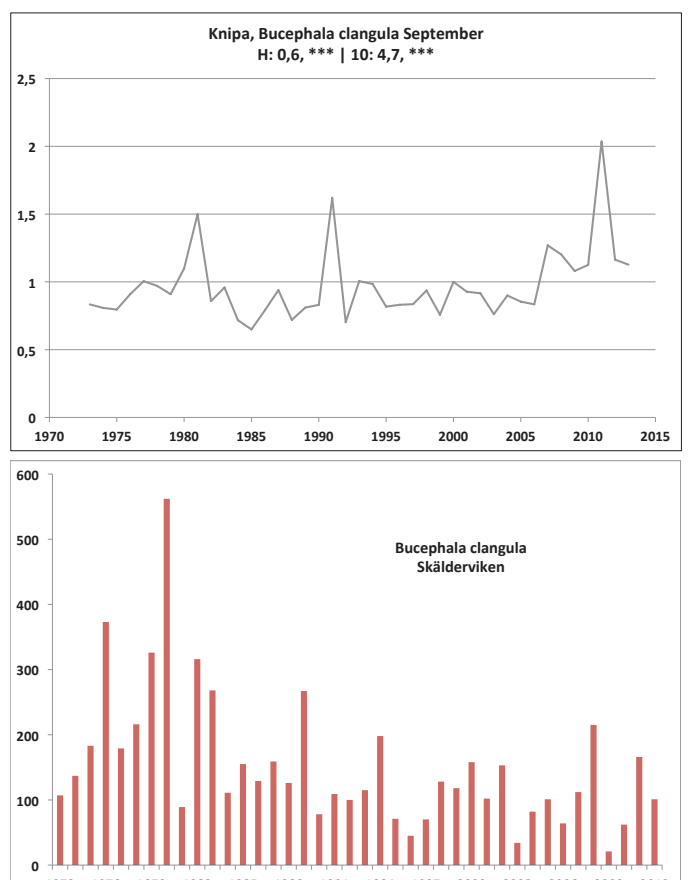

$\begin{array}{llllllllllllll}1973 & 1976 & 1979 & 1982 & 1985 & 1988 & 1991 & 1994 & 1997 & 2000 & 2003 & 2006 & 2009 & 2012\end{array}$

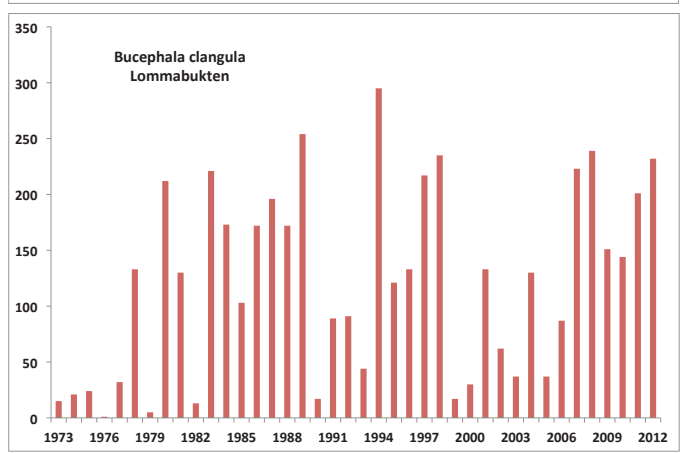

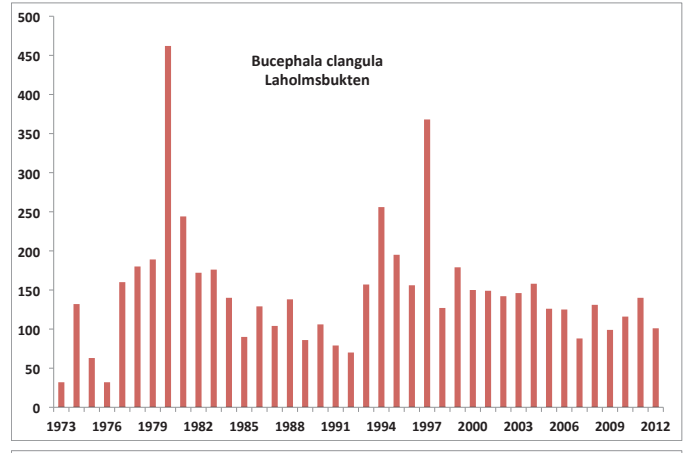
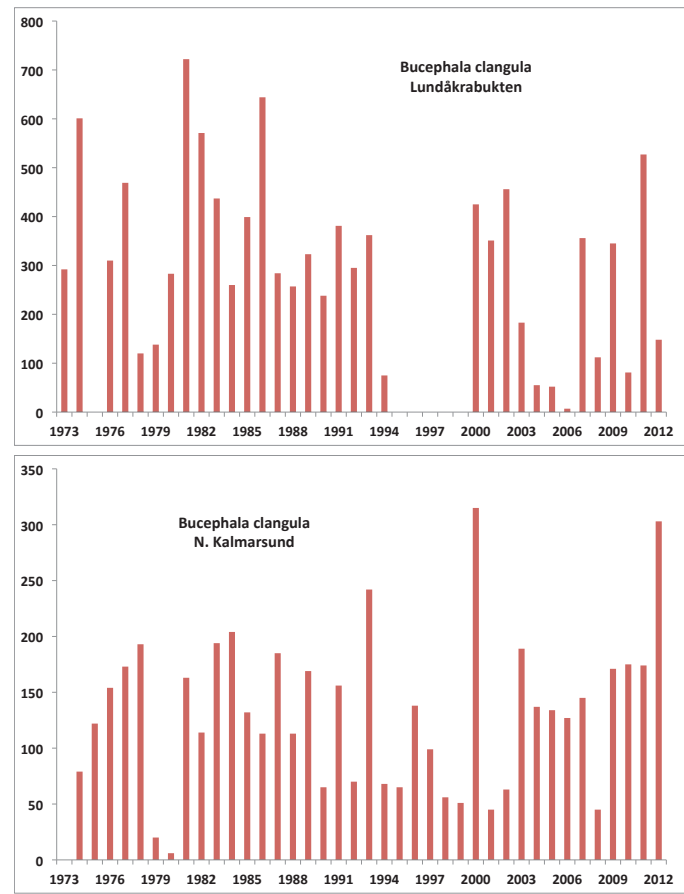

Figure 13. September indices for the Goldeneye Bucephala clangula 1973-2013 and the numbers counted in some reference areas. For more information see Figure 3.

September index för knipa 1973-2013 samt antalet inräknade i några referensområden. Se vidare Figur 3.

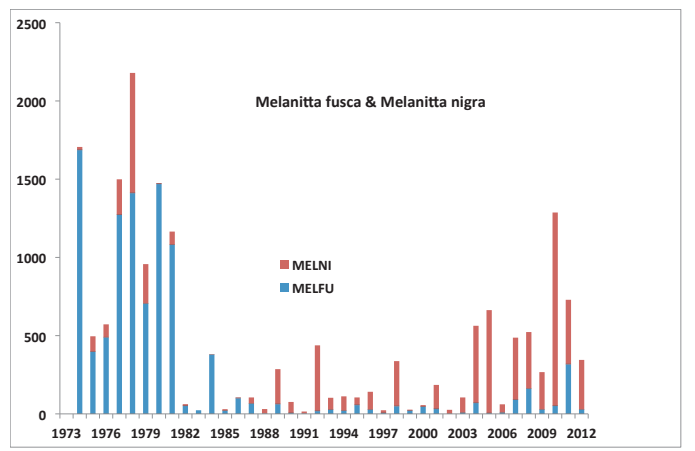

Figure 14. Total number of Velvet Scoters Melanitta fusca and Common Scoters Melanitta nigra counted on the reference areas of the west coast during the September counts in 1974-2012.

Totalantalet inräknade svärtor och sjöorrar i referensområdena på västkusten vid septemberinventeringarna 19742012. 

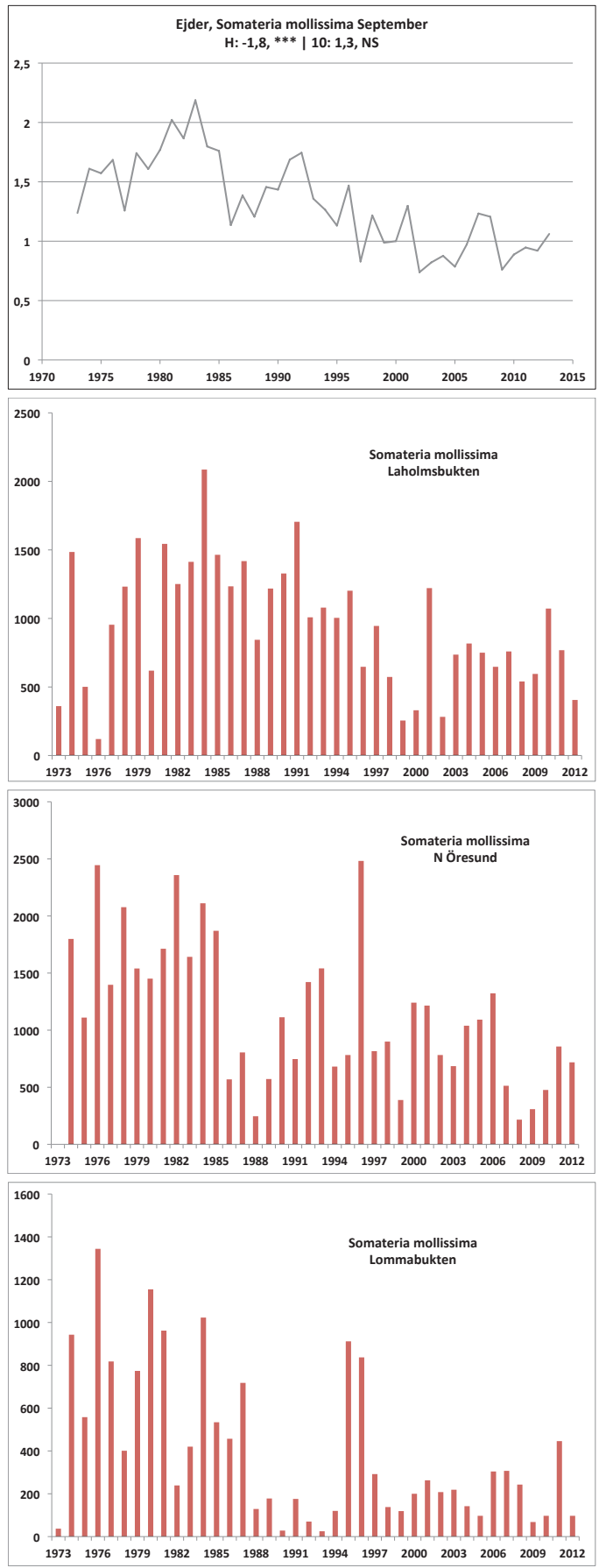
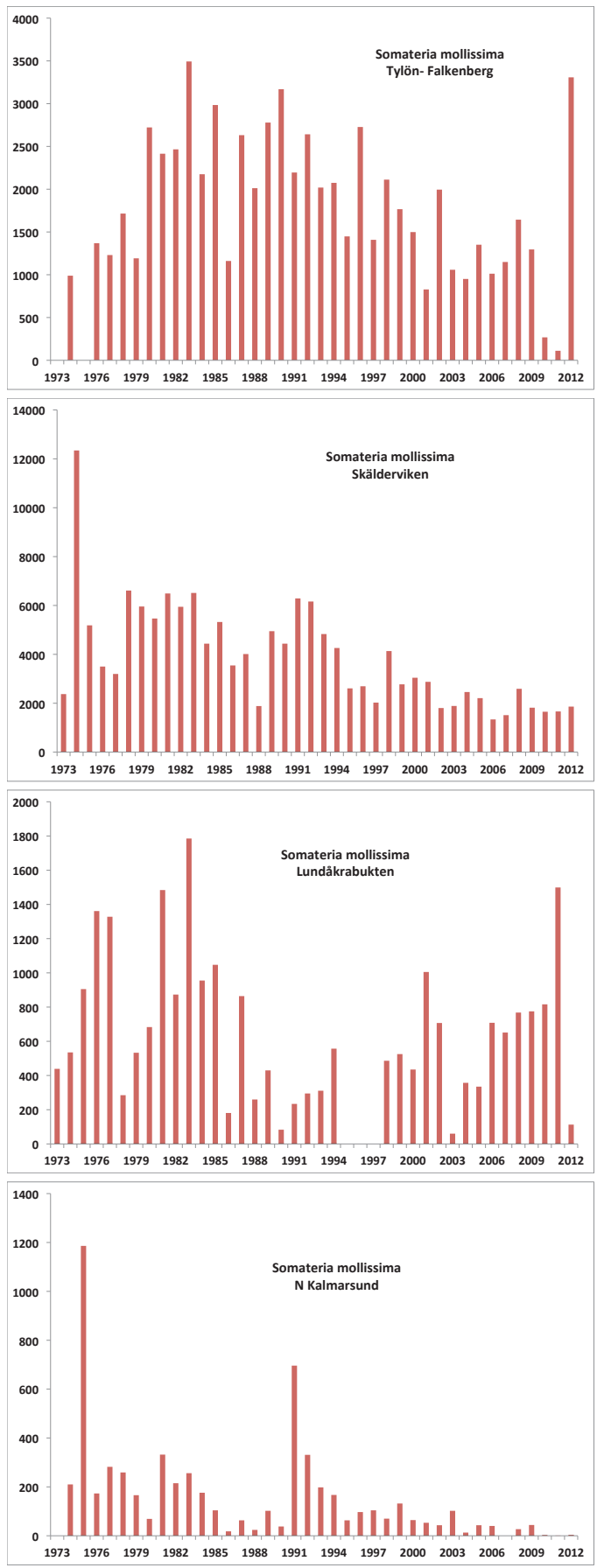

Figure 15. September indices for the Eider Somateria mollissima 1973-2013 and the numbers counted in some reference areas. For more information see Figure 3.

September index för ejder 1973-2013 samt antalet inräknade i några referensområden. Se vidare Figur 3. 


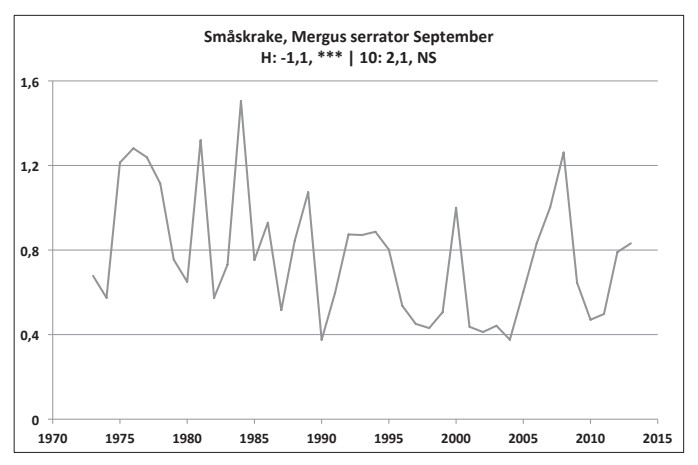

Figure 16. September indices for the Red-breasted merganser Mergus serrator 1973-2013. For more information see Figure 2.

September index för småskrake 1973-2013. Se vidare Figur 2.
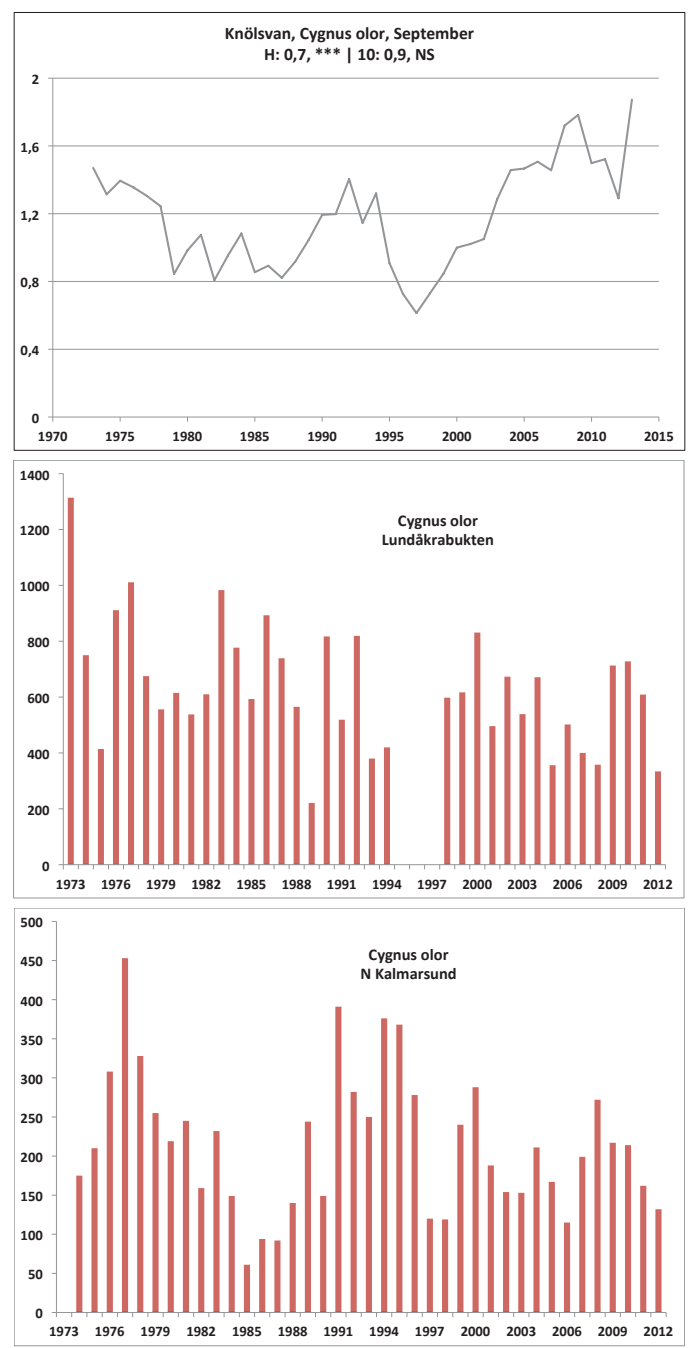

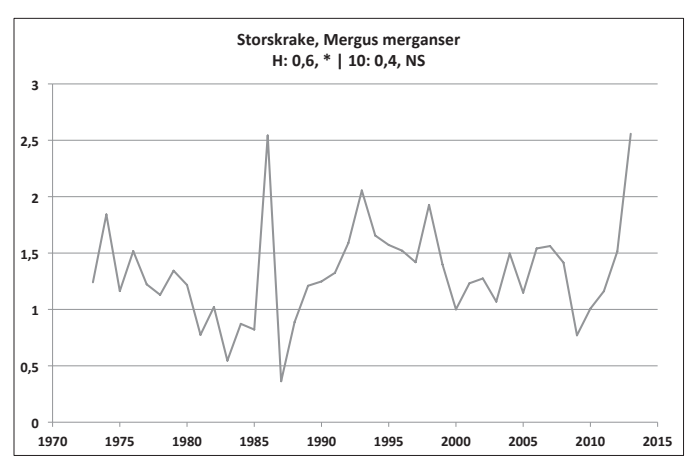

Figure 17. September indices for the Goosander Mergus merganser 1973-2013. For more information see Figure 2. September index för storskrake 1973-2013. Se vidare Figur 2.

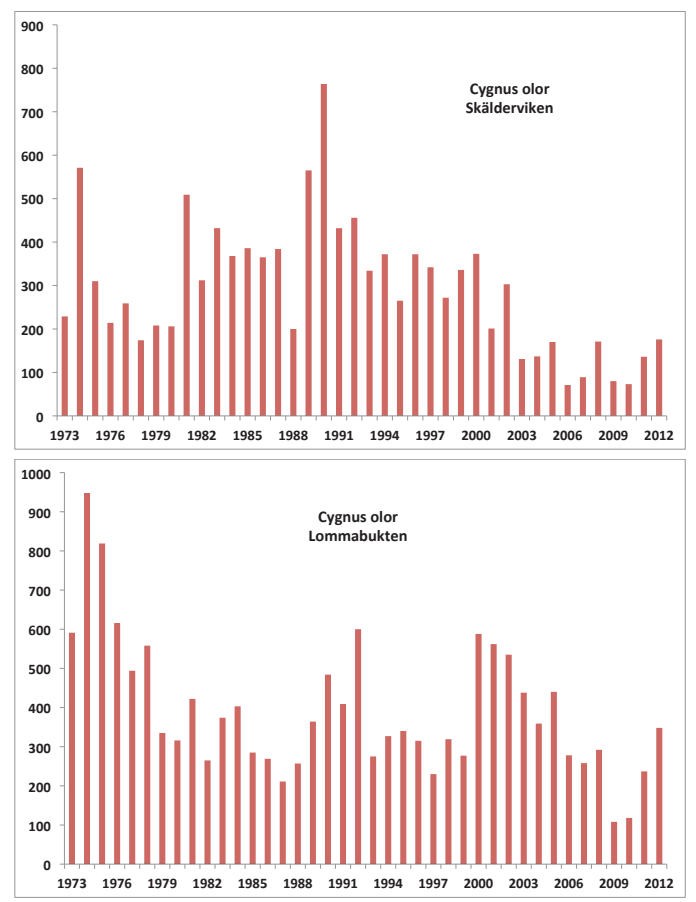

Figure 18. September indices for the Mute Swan Cygnus olor 1973-2013 and the numbers counted in some reference areas. For more information see Figure. 3.

September index för knölsvan 1973-2013 samt antalet inräknade i några referensområden. Se vidare Figur 3. 


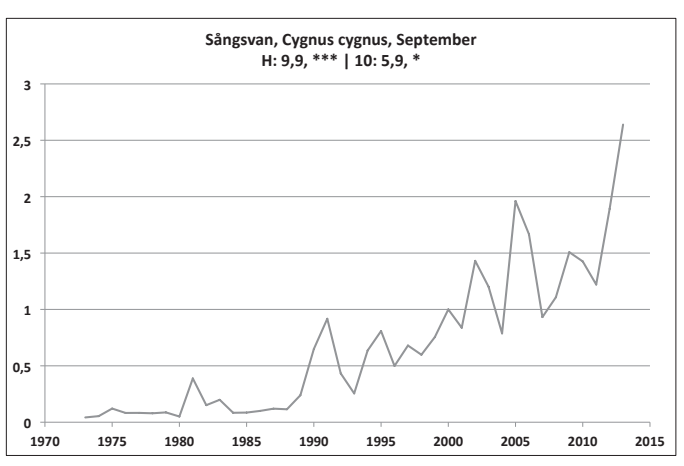

Figure 19. September indices for the Whooper Swan Cygnus cygnus 1973-2013. For more information see Figure 2.

September index för sångsvan 1973-2013. Se vidare Figur 2.

Mute Swan Cygnus olor (Figure 18)

The overall indices show a significantly increasing trend over the entire series, whereas the counts during the last ten years show no significant change. In the reference areas the counts show marked annual fluctuations. A decreasing tendency is seen for the latter part of the period in Skälderviken and for the entire period in Lundåkrabukten.

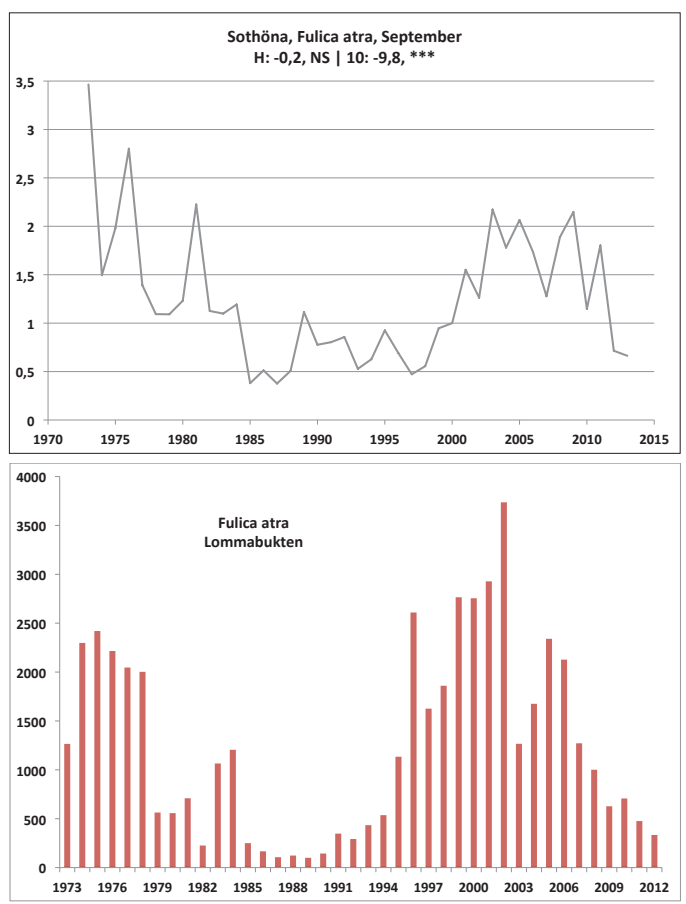

Whooper Swan Cygnus cygnus (Figure 19)

The Whooper Swan showed a significantly increasing trend both for the entire series and for the last decade. The increase started after the cold 1987 winter and before that the indices showed a low and more or less steady level.

Coot Fulica atra (Figure 20)

Large concentrations of Coot have been found in early autumn on Lake Tåkern with between 25000 and 30000 counted in September 1973. Large concentrations of Coot have been a regular feature in this lake over the years even if there is a large variation between years. During the latter part of the period, the newly restored Lake Hornborgasjön also was the site for large concentrations. The counts on these two lakes are very sensitive to wind conditions. In years with hard winds on the days with counts, a large proportion of the Coots can be overlooked behind vegetation. The national indices do not show any significant long-term trend. During the first years of the series the indices were high, followed by a marked drop to a very low level in 1985-1988 related to the very cold winters 19709, 1982, 1985 and 1987, when there
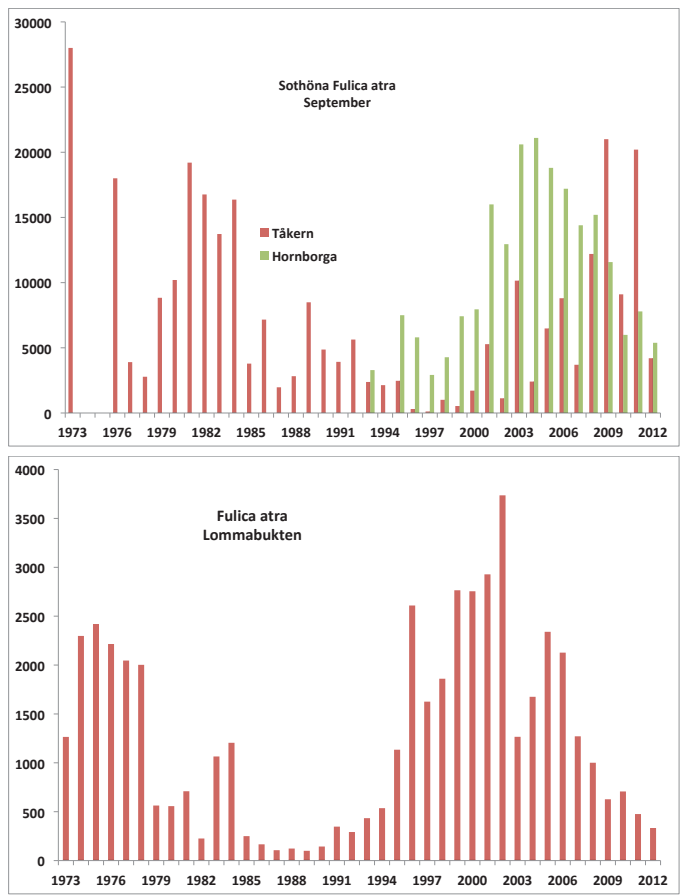

Figure 20. September indices for the Coot Fulica atra 1973-2013 and the numbers counted in some reference areas. For more information see Figure 3.

September index för sothöna 1973-2013 samt antalet inräknade i några referensområden. Se vidare Figur 3. 
was a high mortality among wintering Coot. The level for the indices remained low for a number of years, but then there was a recovery starting in the late 1990s. However, the population has declined again in recent years, so the trend for the last ten years was significantly decreasing. Large numbers of Coot were found in two of the reference areas in Öresund, Lommabukten and Lundåkrabukten. In both areas high numbers were counted during the first years followed by a marked decrease and low counts for a number of years. In Lommabukten there was a marked increase again to high counts for a number of years followed by a decrease during the last few counts. This increase was not so marked in Lundåkrabukten, but there were some years with somewhat higher counts during the last few years.

\section{Discussion}

September indices have been calculated for 18 different waterbird species. Of these species 13 showed a significantly increasing trend over the whole series of 41 years of counts, whereas three species showed significant decreases. In the short term (the last 10 years) six species showed significantly increasing trends, four were decreasing and the others did not show any clear trend. For both the Cormorant and the Heron the long-term trends were significantly increasing but the short-term trends were decreasing.

The trends in a large proportion of the staging waterbird populations as shown in the September indices presented here indicate either a genuine change in numbers in the populations from which the early autumn staging flocks emanate or changes in the staging pattern that might be related to changes in the migration pattern of waterbirds as a response to climate change and a general warming in northern Europe. The effects of climate change on the distribution of wintering waterbirds are well established through the analysis of the results of the International Midwinter Counts (Lehikoinen et al. 2013, Nilsson 2008). The general warming of northern Europe can also affect the timing of migration and the use of different staging areas as has been established for different goose species (Nilsson, 2011, 2013a, Nilsson et al 2013). If there are such changes in the timing of the autumn migration also in the waterbirds discussed here, this could influence the number of staging birds counted in south Sweden during the September counts and thus influence the indices discussed here.

Besides the September waterbird counts present- ed here (and the International Midwinter Counts discussed in detail by Nilsson 2008, see also Nilsson 2014 and Table 2) there are two other monitoring programs that provide trend data for the species discussed here. The Swedish Bird Survey (SBS) provides three sets of indices, i.e. point counts and fixed-route counts for breeding birds and point counts for wintering birds (Green \& Lindström 2014; see also www.zoo.ekol.lu.se/birdmonitoring) and Falsterbo Bird Observatory provides counts of migratory birds at Falsterbo in the autumn (Kjellén 2013; also http://www.falsterbofagelstation.se). The September trends for staging waterbirds as presented here are compared with the trends from these other sets of trend data (Table 2).

The comparison of the long term trends with the other monitoring programs gave the following result. The comparison with the migration counts at Falsterbo could be made for 14 species. The trends agreed for five species and disagreed for one species (Goldeneye) whereas in the other eight species the trends were non-significant in one or both of the series. The comparison with the SBS breeding season point counts could be made for 15 species with agreement of trends in five and disagreement in two (Mallard and Tufted Duck) whereas one or both trends for the other eight species were non-significant. With the IWC midwinter counts 15 species could be compared with ten trends that agreed and three that disagreed (Mallard, Eider and Red-breasted Merganser) whereas two trends were non-significant in September. In the comparison, with the SBS winter point counts, 12 species could be included. Trend agreement was found for nine and disagreement for two species (Mallard and Eider); two species had non-significant trends in one of the series. In conclusion, the best agreements were found with the two midwinter counts whereas the agreement with the two breeding bird counts and the migration count was less good. One species, the Mallard, stands out as the September index disagreed with that from all the other series. The Eider index disagreed with both the other winter counts.

Among the species discussed here, two species, the Mallard and the Tufted Duck, showed different long-term trends for the September counts and the SFT breeding season point counts, whereas this was the case for one species, the Goldeneye, in the comparison with the Falsterbo migration counts. In these cases changes in the migration pattern might be involved. In contrast to these differences five species for both comparisons showed similar trends indicating that the indices reflect real changes in the populations. 
Table 2. Trends in the number of waterbirds in Sweden according to different monitoring programs: (1) the International Waterbird Counts (IWC) in September (present contribution), (2) the IWC midwinter counts (Nilsson 2014), (3) the counts of autumn migration at Falsterbo Bird Observatory (Kjellén 2013), (4) the point counts of breeding birds in the Swedish Bird Survey (SBS; Green \& Lindström 2014), (5) the SBS fixed route counts of breeding birds, and the SBS point counts of wintering birds. Increasing $(+)$ and decreasing $(-)$ trends are marked with a sign if significant. $* \mathrm{P}<0.05, * * \mathrm{P}<0.01$ and $* * * \mathrm{P}<0.001, \mathrm{NS}=$ no significant trend.

Jämförelser av trender $i$ antalet vattenfäglar $i$ Sverige enligt olika inventeringsprogram: (1) Internationella sjöfågelinventeringen (IWC) i september (denna uppsats), (2) midvinterinventeringen inom IWC (Nilsson 2014), (3) räkningar av höstflyttande fåglar vid Falsterbo fågelstation (Kjellén 2013), (4) inventering av punktrutter under häckningstid inom Svensk Fågeltaxering (SFT; Green \& Lindström 2014), (5) inventering av standardrutter under häckningstid inom SFT) och (6) inventering av punktrutter vintertid inom SFT. Ökande (+) och minskande (-) trender markeras med tecken om signifikanta. . $* P<0.05, * * P<0.01$ och $* * * P<0.001, N S=$ inte signifikant.

\begin{tabular}{|c|c|c|c|c|c|c|c|}
\hline & \multicolumn{5}{|c|}{ Long-term trends } & \multicolumn{2}{|c|}{ Short-term trends } \\
\hline & $\begin{array}{l}\text { September } \\
\text { IWC } \\
1975-2013\end{array}$ & $\begin{array}{l}\text { Autumn } \\
\text { migration } \\
1973-2012 \\
\end{array}$ & $\begin{array}{l}\text { Breeding } \\
\text { point counts } \\
1975-2013\end{array}$ & $\begin{array}{l}\text { Midwinter } \\
\text { IWC } \\
1967-2014\end{array}$ & $\begin{array}{l}\text { Midwinter } \\
\text { point counts } \\
1975-2013\end{array}$ & $\begin{array}{l}\text { September } \\
\text { IWC } \\
2004-2013\end{array}$ & $\begin{array}{l}\text { Breeding } \\
\text { fixed routes } \\
2000-2013\end{array}$ \\
\hline Podiceps cristatus & NS & & NS & $+* * *$ & & $-* *$ & NS \\
\hline Phalacrocorax carbo & $+* * *$ & & $+* * *$ & $+* * *$ & $+* * *$ & -* & $+* * *$ \\
\hline Ardea cinerea & $+* * *$ & & $+*$ & $+* * *$ & $+* * *$ & -* & $-* * *$ \\
\hline Anas platyrhynchos & $-* * *$ & NS & $+* * *$ & $+* * *$ & $+* * *$ & NS & $+*$ \\
\hline Anas crecca & $+* * *$ & NS & NS & $+* * *$ & & $+* * *$ & $-*$ \\
\hline Anas penelope & $+* * *$ & $+* * *$ & NS & $+* * *$ & NS & NS & $-* *$ \\
\hline Anas strepera & $+* * *$ & $+* * *$ & & & & $+* * *$ & \\
\hline Anas acuta & $+* * *$ & $+* * *$ & & & & NS & \\
\hline Anas clypeata & $+* * *$ & $+* * *$ & & & & $+*$ & \\
\hline Aythya fuligula & $+* * *$ & NS & -* & $+* * *$ & $+* * *$ & NS & $-* *$ \\
\hline Aythya ferina & $+* * *$ & NS & NS & $+* * *$ & $+*$ & $+* * *$ & \\
\hline Bucephala clangula & $+* * *$ & $-* * *$ & NS & $+* * *$ & $+* * *$ & $+* * *$ & $-*$ \\
\hline Melanitta fusca & & $+*$ & & $-*$ & & & NS \\
\hline Melanitta nigra & & $+* * *$ & & $+* * *$ & & & NS \\
\hline Somateria mollissima & $-* * *$ & NS & $-* * *$ & $+* * *$ & $+*$ & NS & NS \\
\hline Mergus serrator & $-* * *$ & NS & NS & $+* * *$ & NS & NS & NS \\
\hline Mergus merganser & $+*$ & NS & NS & $+* * *$ & $+* * *$ & NS & NS \\
\hline Cygnus olor & $+* * *$ & NS & $+* *$ & $+* * *$ & $+* * *$ & NS & NS \\
\hline Cygnus cygnus & $+* * *$ & $+* * *$ & $+* * *$ & $+* * *$ & $+* * *$ & $+*$ & $+* *$ \\
\hline Fulica atra & NS & & NS & $+* * *$ & NS & $-* * *$ & NS \\
\hline
\end{tabular}

The short term trends are less well in agreement than the long-term ones. Fourteen species can be compared. Nine of them show non-significant trends in one of the series. The trends that are significant in both series agree in two and disagree in three species. It is likely that ten years is a period that is too short for the large inter-annual variations to permit revelation of significant trends unless they are very dramatic.

In the Cormorant and the Heron, both the longterm September indices and the point counts show significantly increasing trends. On the other hand, the short-term September trends were decreasing as was the trend from the Fixed-routes for breeding herons. For the Heron at least this could probably be related to the cold winters in 2010 and 2011, the species being sensitive to cold winters. The trends for the Cormorant reflect the general increase of the Cormorant populations in Sweden and other countries.

In the dabbling ducks, significantly increasing trends were found both for the long-term September indices and in the number of migrants at Falsterbo for the Wigeon, Pintail, Shoveler and Gadwall. In the Wigeon and the Pintail there were no clear trends in the short-term indices. The Mallard showed a significant decrease in the long-term September indices, whereas the Teal showed increasing trends both long-term and short-term. There was no clear tendency in the Falsterbo counts for these two species. The breeding bird indices showed an increase in the Mallard for both the Point counts and the Fixed-routes, whereas there was a decrease in the Fixed-route index for the Teal.

The general tendency for the Mallard in the region is an increase (Dalby et al. 2013). The staging Mallards in south Sweden may be of both local origin and from areas further to the northeast. It is possible that the general tendencies to an earlier spring have changed the timing of breeding and indirectly the timing of autumn migration thus causing the observed trend in staging September numbers. 
For the smaller diving ducks, the long-term September trends were significantly increasing as were the short-term trends except for the Tufted Duck. The number of Goldeneyes passing Falsterbo on migration showed an opposite trend, which might be related to changes in the migration pattern, a higher proportion of the Goldeneyes staying for a longer period in the country. It was expected that the increasing trend for the Goldeneye in the September counts should also be reflected in the breeding bird surveys, but the long-term Point-counts did not show any trend, whereas the Fixed-routes showed a decrease.

The Eider was one of the three species showing a significantly decreasing long-term trend. The same trend was found in the Point counts (Table 2). These trends reflect the general trend of a marked decrease in the Eider populations of the Baltic region (Ekroos et al. 2012). No short-term trends were found for the Eider.

Both swan species show increasing trends, the Whooper Swan for all indices shown in the comparison in Table 2, whereas increasing trends were found in the long-term September indices and the Point counts for the Mute Swan. Another species covered by both the September counts and the breeding bird surveys is the Coot. This species shows a similar picture both during the breeding season and in the September counts..

The January indices on the other hand mostly show significantly increasing trends (Nilsson 2008, $2013 b, 2014)$. The winter point counts in Sweden (Green \& Lindström 2014) show a similar picture for the waterbirds. The increases in January totals for a number of waterbirds is mostly due to changes in the distribution in relation to milder winters (Lehikoinen et.al. 2013), but the increases can of course also be a combination of changed winter distribution in relation to milder winters and a genuine population increase.

\section{Acknowledgements}

The counts were all undertaken by voluntary observers who covered their areas year by year during an often very long time. Without all those hundreds of observers this study could not have been done, so my sincere thanks go to all duck counters that go out to our water areas year after year both during autumn and winter.

\section{References}

Atkinson-Willes, G.L. 1969. The midwinter distribution of Wildfowl in Europe, northern Africa and southwest Asia, 1967 and 1968. Wildfowl 20: 98-111.

Austin, G.E., Read, W.J., Calbrade, N.A., Mellan, H.J. Musgrove, A.J., Skellorn ,A.J., Hearn, R.D., Stroud, D.A., Wotton, S.R. \& Holt, C.A. 2014. Waterbirds in the UK 2011/12. The Wetland Bird Survey. BTO,.RSPB and JNCC, in association with WWT. British Trust for Ornithology, Thetford.

Dalby, L., Söderquist, P., Christensen, ,T.K., Clausen, P., Einarsson, A., Elmberg, J.,. Fox, A.D., Holmqvist, N., Langendoen, T., Lehikoinen, A., Lindström, Å., Lorentsen, S-H, Nilsson, L. Pöysä, H., Rintala, R.,.. Sigfússon,A. \& Svenning. J-C. 2013.The status of the Nordic populations of the Mallard (Anas platyrhynchos) in a changing world. Ornis Fennica 90: 2-15.

Delany, S. \& Scott, D. 2006. Waterbird Population Estimates. Fourth Edition. Wetlands International. Wageningen, the Netherlands.

Ekroos, J., Fox, A.D., Christensen,T.K., Petersen, I.K., Kilpi, M., Jonson, J.E., Green,M., Laursen, K., Cervencl, A., de Boer,P., Nilsson, L. Meissner, W., Garthe, S. \& Öst, M.). 2012. Declines amongst breeding Eider Somateria mollissima numbers in the Baltic/Wadden Sea flyway. Ornis Fennica 89: 81-90.

Gilissen, N., Haanstra, L., Delany, S., Boere, G. \& Hagemeijer, W. 2002. Numbers and distribution of wintering waterbirds in the Western Palearctic and Southwest Asia in 1997, 1998 and 1999. Results from the International Watebird Census. Wetlands International Global Series 11. Wageningen, the Netherlands.

Green, M. \& Lindström. Å. 2014. Övervakning av fåglarnas populationsutveckling. Arsrapport för 2013. Biologiska Institutionen, Lunds Universitet, Lund 2014.

Hornman, M., Hustings, F., Koffijberg, K., Klaassen, O., van Winden, E., Sovon Ganzen- en Zwanenverkgroep \& Soldat, L. 2013. Watervogels in Nederland in 2010/2011. SOVON-rapport 2013/02.

Joensen, A.H. 1968. Wildfowl Counts in Denmark in November 1967 and January 1968 - Methods and Results. Danish Review of Game Biology 5(5): 1-72.

Joensen, A.H. 1974. Waterfowl Populations in Denmark 1965 - 1973. A Survey of the Non-breeding Populations of Ducks, Swans and Coot and their Shooting Utilization. Danish Review of Game Biology 9: 1-206.

Kjellén, N. 2013. Sträckfågelräkningar vid Falsterbo hösten 2012. Fåglar i Skåne 2012: 5-48.

Lehikoinen, A., Jaatinen,K., Vähätalo, A.V., Clausen.P., Crowe,O., Deceuninck, B., Hearn, R., Holt, C.A., Hornman, M., Kewller, V., Langedoen, T., Nilsson, L, Tomankova, I., Wahl, J. \&, Fox, A. D. 2013. Rapid climate driven shifts in wintering distributions of three common waterbird species. Global Change Biology 19: 2071-2081

Nilsson, L. 1968. Seasonal Fluctuations in Numbers of Swedish Winter Ducks. Vår Fågelvärld 27: 142-171.

Nilsson, L. 1975. Midwinter distribution and numbers of Swedish Anatidae. Ornis Scandinavica 6: 83-107.

Nilsson, L. 1976. Monthly counts as a measure of population changes in some species of Anatidae in south Sweden. Ornis Scandinavica 7: 193-205.

Nilsson, L. 1977. November distribution and numbers of 
Swedish Anatidae. Viltrevy 10: 41-77.

Nilsson, 1980a. Änders, svanars och vissa sjöfåglars utbredning och antal i september i södra Sverige. Vår Fågelvärld 39: 277-290.

Nilsson, L. 1980b. Marsinventeringar av änder, svanar och vissa andra sjöfåglar i södra Sverige 1976-1979. Vår Fågelvärld 39: 149-160.

Nilsson, L. 2008. Changes in numbers and distribution of wintering waterfowl in Sweden during forty years, 19672006. Ornis Svecica 18: 135-226.

Nilsson, L. 2011. The migrations of Finnish Bean Geese Anser fabalis in 1978-2011. Ornis Svecica 21: 157-166.

Nilsson, L. 2013a. Censuses of autumn staging and wintering goose populations in Sweden 1977/1978 - 2011/2012. Ornis Svecica 23: 3-45.

Nilsson, L. 2013b. Internationella sjöfågelinventeringarna i Sverige. Sid 51-64 in SOF 2013. Fågelåret 2012. Vår Fågelvärld, supplement nr 53.

Nilsson, L. 2014. Inventering av sjöfågel och gäss $i$ Sverige. Arsrapport för 2013/2014. Biologiska Institutionen, Lunds Universitet.

Nilsson, L., Follestad, A., Guillemain, M., Schricke, V. \& Voslamber, B. 2013. France as a staging and wintering area for Greylag Geese Anser anser. Wildfowl 63: 24-39

Owen, M., Atkinson-Willes, G.L., Salmon, D.G. 1986. Wildfowl in Great Britain. Second Edition. Cambridge University Press, Cambridge, UK.

Pannekoek, J. \& van Strien, A.J. 2001. TRIM 3 Manual. TRends and Indices for Monitoring Data. StatisticsNetherlands, Voorburg, Research paper no. 0102.

\section{Sammanfattning}

Under mitten av 1960-talet insåg man att det krävdes samordnade insatser för att följa trenderna i de olika andfågelbestånden samt för att fastställa viktiga områden för de olika arterna, varför man startade de internationella midvinterinventeringarna $\mathrm{i}$ januari 1967 (Atkinson-Willes 1969). Januari valdes för att andfåglarna under denna månad vistades i de tättbefolkade delarna av Europa och var som mest koncentrerade, vilket underlättade inventeringarna. Sverige har varit med i dessa inventeringar sedan starten 1967 (Nilsson 1975, 2008, 2013b).

För att täcka situationen under andra delar av säsongen organiserades också under några år räkningar i november, mars och september (svenska referenser se Nilsson 1977, 1980a, 1980b). Septemberinventeringarna, som startade 1973, har sedan fortsatts varje år för att ge underlag för att följa de rastande sjöfågelbestånden $i$ landet under den tidiga hösten. Ursprungligen omfattade de internationella sjöfågelinventeringarna änder och svanar, men arturvalet utökades senare till att också omfatta lommar, doppingar, häger, storskarv och sothöna. Alla dessa arter ingår i septemberinventeringen. Gässen ingår också i de internationella midvinterinventeringarna och är dessutom föremål för speciella gåsinventeringar under hösten. Resultaten från dessa inventeringar har publicerats tidigare (Nilsson 2013a).

I denna uppsats analyseras de första fyrtioen årens inventeringar av rastande sjöfåglar i Sverige i september. Huvudvikten är att belysa förändringarna i antal mellan olika år och speciellt att belysa den ev. förekomsten av långtids (hela perioden) och korttidstrender i bestånden av olika rastande sjöfågelarter i södra Sverige. Septemberindex för olika arter publiceras regelbundet $i$ årliga rapporter som bl.a. går ut till deltagarna och kan också återfinnas på projektets hemsida med detaljer från de årliga inventeringarna: http://www.zoo.ekol.lu.se/ waterfowl/index.htm

\section{Material och metoder}

Andfågelinventeringarna i Sverige liksom i övriga länder baseras helt på frivilliga observatörer, som täcker en eller flera räkningsenheter vid de aktuella inventeringarna. Genom åren har det byggts upp ett nätverk av observatörer och grupper av observatörer som varje år täcker sina inventeringsområden. Septemberinventeringen genomförs veckoslutet närmast den 15:e med de närmaste dagarna som reservtid.

Efter de första årens inventeringar delades den svenska kusten in i räkningssektorer som var så valda att de lätt kunde återfinnas i fält och inte var större än att man kunde räkna dem fullständigt under en och samma dag. Vanligen kunde en inventerare täcka flera enheter. I samband med midvinterinventeringarna på 1980-talet etablerades ett antal referensområden, vilka täcktes på ett standardiserat sätt varje år. Sju av dessa områden inventeras också i september vartill kommer ett antal mer spridda inventeringslokaler (Figur 1).

Populationsindex för de olika arterna har beräknats enligt TRIM-metoden (Pannekoek \& van Strien (2001). Metoden är densamma som används av Svensk Fågeltaxering (Green \& Lindström 2014). I tidigare rapporter och publikationer beräknades index som kedje-index, varför en del skillnader kan föreligga, mellan denna publikation och tidigare.

Inventeringarnas täckning under senare år visas i Figur 1, medan antalet inventerade lokaler under olika år framgår av tabell 1. Under de första åren inventerades något fler lokaler än senare, speciellt 1974 (Nilsson 1980a), då vissa delar flyginventerades. 
Resultat

Septemberindex för södra Sverige har kunnat beräknas för 18 olika arter och presenteras i en serie diagram för de olika arterna både för hela serien (41 år) och för de senaste 10 åren Totalt sett visade 13 arter signifikanta ökande trender i långtidsindex för september, medan tre arter visade signifikanta nedåtgående trender för samma period. När det gäller korttidstrenden var sex arter ökande, medan fyra arter visade en minskande trend.

Långtidsserien visar ingen klar trend för skäggdoppingen (Figur 2), medan arten minskat under den senaste tioårsperioden. Storskarv och häger (Figur 3, 4) visade ökande trender för hela serien, medan båda arterna minskade den senaste tioårsperioden. För hägern torde detta förmodligen kunna hänföras till de kalla vintrarna 2010 och 2011.

Samtliga simänder utom gräsanden visade signifikanta ökande långtids trender (Figur 5 - 10), medan korttidstrenderna ökade för tre av arterna. Ökningen var mest markant för snatteranden som endast noterades i enstaka individ vid de första septemberinventeringarna, men som från år 2000 ökat markant som rastare, särskilt på de stora fågelsjöarna Tåkern och Hornborgasjön (Figur 8).

De tre små dykänderna vigg, brunand och knipa visade alla signifikant ökande långtidstrender (Figur 11-13). Ö̉kningen var särskilt markant för brunanden, där septembersummor om mer än 20000 individ noterats vid Tåkern vissa år (Figur 12).

Båda de havslevande dykänderna, ejder (Figur 15) och småskrake (Figur 16), visade signifikant minskande långtids trender, medan korttidstrenderna inte visade någon klar bild. Däremot förekom svärta och sjöorre i någorlunda antal endast i Laholmsbukten och i viss mån Skälderviken. Antalet rastare varierade markant mellan olika år (Figur 14).

Både knölsvan och sångsvan visade signifikant ökande långtidstrender (Figur 18, 19). Däremot visade sothönan ingen klar långtidstrend (Figur 20).

\section{Diskussion}

Som framgått ovan visade 13 av de 18 undersökta arterna signifikant ökande långtids trender, medan tre arter minskade och två inte visade någon klar långtidstrend. för tre arter visade korttidstrenden en nedgång, som troligen kan förklaras av ett par kalla vintrar under perioden.

De trender som diskuterats här kan jämföras med trenderna för samma arter från två andra övervakningsprogram. 1) Svensk Fågeltaxering med punktinventeringar sommar och vinter samt standardrutter under häckningstiden ((Green \& Lindström 2014 se också www.zoo.ekol.lu.se/birdmonitoring) samt 2) de regelbundna flyttfågelräkningarna vid Falsterbo (Kjellén 2013, http://www.falsterbofagelstation.se ). I flertalet fall visar jämförelserna mellan septemberindex och de andra programmen liknande trender även om det förekommer en del skillnader (Tabell 2). Sålunda minskar gräsandens septemberindex, medan någon sådan tendens inte finns i sträcksiffrorna. Däremot visar index från punktinventeringarna på sommaren en signifikant ökning. Denna skillnad mellan de båda dataserierna kan kanske förklaras av ändrade flyttningsvanor i samband med att klimatet under vintern och våren blivit varmare.

Vinterindex (både sjöfågelinventeringarna och punktrutterna) visar för de flesta arter signifikant ökande trender, vilket torde kunna relateras till de mildare vintrarna under senare år. 